\title{
Mitos, arquétipos e novas representações de gênero em contos juvenis contemporâneos
}

Myths, archetypes and new gender representations in contemporary youth tales

\section{Lívia Maria Rosa Soares ${ }^{\mathrm{I}}$}

1 Doutoranda em Letras pela Universidade Estadual do Rio Grande do Norte. Mestre em Letras pela Universidade Estadual do Piauí. Atualmente, é professora EBTT do Instituto Federal de Educação, Ciência e Tecnologia do Maranhão (IFMA), atuando nos ensinos médio e técnico. E-mail: livia. soares@ifma.edu.br. 
RESUMO: Este trabalho pretende analisar a influência mítica e simbólica nos contos juvenis Maria, Maria e Com sua voz de mulher de Marina Colasanti. A partir disso, se pretende investigar como as identidades de gênero se atualizam e são reafirmadas a partir das metáforas e alegorias presentes nas narrativas juvenis contemporâneas, uma vez que elas redimensionam as representações dos papéis de gênero na pós-modernidade. Assim, ao relacionarmos as identidades femininas em tempos e espaços distintos em narrativas ficcionais, julgamos avançar no desvendamento das máscaras ideológicas reproduzidas em épocas distintas e entender como esses contos contribuem para a compreensão dos embates ideológicos vivenciados socialmente.

PALAVRAS-CHAVE: Representações de gênero: Tradição: Pós-modernidade: Contos juvenis.

ABSTRACT: This work intends to analyze the juvenile tales: Maria, Maria and With Her Voice of woman of Marina Colasanti. It is intended to investigate how gender identities are updated and are reaffirmed from the metaphors and allegories presents in contemporary juvenile narratives, once they reshape the representation of gender roles in postmodernity. Thus, when we relate feminine identities in different times and spaces in fictional narratives, we judge that we advance in the unraveling of the ideological masks reproduced in different epochs and understand how these stories contribute to the understanding of the socially experienced ideological clashes.

KEYWORDS: Gender representations: Tradition: Postmodernity: Juvenile tales. 


\section{Perfis femininos nos contos de fadas tradicionais e pós-modernos: um breve histórico}

Qual o valor de uma obra literária? Qual a relação dela com obras que a sucederam? Essas perguntas certamente teriam respostas diversas. Porém, ao considerarmos a linha de pesquisa Literatura juvenil e a análise da produção literária destinada a este público específico, percebemos que algumas características observadas nas produções atuais se aproximam e ao mesmo tempo se distanciam dos modelos tradicionais que se adaptaram a diferentes culturas e momentos históricos e chegaram até os nossos dias.

Essas reflexões retomam a gênese da literatura destinada às crianças e jovens, uma vez que presenciamos, em pleno século XXI, o ressurgimento de uma estrutura antiga, porém atualizada aos paradigmas pós-modernos. Por isso, considerando a história e a evolução desse gênero literário, percebe-se que a forma como o conto de fadas foi desenvolvido ao longo da história traz traços que representavam de maneira exemplar a mentalidade pragmática que se consolidava na época, especialmente em relação às funções femininas.

As maneiras de representar os papéis de gênero nas narrativas infantis e juvenis ficaram bem marcadas em vários contos de fadas tradicionais e resistem até hoje. Sobre essa questão, na obra Em busca dos contos perdidos, a pesquisadora Mariza B. T. Mendes (1999) fez uma análise dos significados das funções femininas em oito contos de Charles Perrault considerado o precursor das narrativas infantis, destacando neles os prêmios e castigos que a sociedade patriarcal determinou às mulheres:

\footnotetext{
Os prêmios e castigos para as boas e más ações são a base da moral ingênua, que caracteriza as narrativas de origem popular. As mulheres recebem castigos especiais, que mostram o modo como o sexo feminino é manipulado na sociedade. $\mathrm{O}$ uso dos mitos nos contos de fadas em todas as culturas, sempre teve o objetivo de preservar as bases morais e ideológicas da sociedade patriarcal (MENDES, 1999, p. 111).
}

A autora mostra a partir da interpretação dos contos clássicos que os atributos das personagens femininas logo saltam aos olhos. Cinderela, Bela Adormecida e Chapeuzinho Vermelho são dóceis e amáveis, lembram as garotas ingênuas e desprotegidas. As fadas lembram 
a mãe protetora e as bruxas lembram a madrasta, a mãe malvada. Essas características definem a imagem da mulher que o artista captou em uma determinada época e transmitiu à posteridade, permanecendo após três séculos em diversas produções destinadas a todos os públicos.

Uma das hipóteses para o destaque dado às funções femininas nessas histórias "está na relação dos contos com os mitos, que por sua vez se originaram de rituais praticados nas comunidades primitivas. Nelas, as mulheres tinham um papel social importante de sacerdotisa e as divindades eram femininas" (MENDES, 1999, p. 125). As histórias clássicas trazem em seus enredos mulheres passivas à espera da figura masculina que quase sempre exercia papel de decisão. Nesse sentido, os enredos enfatizam o perfil da mulher ideal para que não pairassem dúvidas quanto ao seu papel social, ou seja, imaginação e verdade se colocam como alteridades que interagem, mas não se excluem mutuamente.

Evidenciam-se duas características comuns entre os contos de fadas tradicionais e pós-modernos: as protagonistas são mulheres, que enfrentam alguma espécie de ordem constituída, mas a principal e mais desafiadora é a política. O fato de as personagens pertencerem ao sexo feminino é circunstancial: faculta a concentração temática e sublinha o efeito liberador em relação a algum aspecto desafiador do mundo ficcional. Bettelheim (2009), exemplifica essa característica ao citar que:

Para Chapeuzinho Vermelho, o mundo para além do lar paterno não é um ermo ameaçador através do qual a criança não consegue encontrar um caminho. Para lá do portão da casa de Chapeuzinho Vermelho há uma estrada bem conhecida, da qual sua mãe previne que não se desvie (...) esse dilema de situar-se entre o princípio da realidade e o princípio de prazer é afirmado explicitamente quando o lobo diz à menina: "Veja como são as belas flores ao seu redor. Por que não dá uma olhada por aî? Acho que você nem ouve como os passarinhos cantam bonito. Caminha atenta e concentrada como se fosse para a escola, enquanto que aqui na floresta tudo é alegria". Esse é o mesmo conflito entre fazer o que se gosta de fazer e o que deve fazer (BETTELHEIM, 2009, p. 14).

A narrativa mundialmente conhecida e adaptada mostra que a protagonista, após ter desobedecido às recomendações aprende a lição: "prometendo não mais se desviar do caminho 
para se embrenhar na floresta...”. Por isso não existe uma conspiração dos adultos para forçar a heroína da história a corrigir seu caminho como exige a sociedade - "um processo que nega o valor do direcionamento íntimo" (BETTELHEIM, 2006, p. 38).

Assim, os mitos e contos de fadas são textos que permitem a expressão da alma mesmo em tempos bem distantes. Essas narrativas priorizam as representações femininas e ajudam a entender o processo de dinamização de construções simbólicas e podem auxiliar no entendimento acerca das representações de gênero.

Ressalte-se que as imagens representadas nas obras e a sua dinâmica estão associadas a símbolos, cujas formas contêm sentidos psicológicos universais e remetem para as estruturas biopsicológicas e socioculturais, construções do pensamento que representam o mundo exterior através dos recursos da linguagem como a metáfora, que é responsável pela poeticidade.

É importante considerar que os arquétipos presentes nos mitos e nos contos de fadas remontam a imagens primordiais e universais, o que revela a presença de imagens simbólicas. Diante disso, analisaremos em que medida a representação feminina nos contos selecionados abre-se a reflexões existenciais, arquétipos do inconsciente coletivo, cujas formas possuem sentidos universais que se atualizam com o contexto sociocultural de cada época, representando o mundo exterior através de recursos da linguagem e da memória.

Eternizados através da arte, os mitos e os contos clássicos mantêm uma forte ligação com a literatura, visto que esta é também uma forma pela qual o homem busca uma compreensão de si e dos enigmas próprios do “estar no mundo”, como afirma Eliana Yunes (1998): "o mundo organizado se desorganiza, o mundo caótico ganha sentido, o fantástico é experimentado, a história ganha condições de maravilhoso e o maravilhoso de verdade" (YUNES, 1998, p. 189). Desse modo, a matéria literária dos contos de fadas ganha um novo sentido, ou seja, ainda apresenta relações com o imaginário popular, perpetuando-se através dos séculos.

Ao lado da dimensão social e histórica que os contos juvenis registram, há um sedimento primitivo que se manifesta pela presença de elementos míticos e de rituais de passagem comuns nas sociedades arcaicas. Além disso, esses textos são descendentes de fontes remotas, por isso guardam uma herança arquetípica que representa a bagagem cultural acumulada ao longo dos séculos. Como afirma Maria Zaira Turchi (2006), “é uma generalização dinâmica 
e afetiva da imagem, promove a união entre os gestos inconscientes e as representações, formando o esqueleto dinâmico da imaginação" (TURCHI, 2006, p. 28).

Aliada a essa questão, a análise da representação feminina no passado e no presente pode ajudar a entender questões relacionadas à pluralidade cultural na literatura brasileira contemporânea para crianças e jovens no que tange a representação de grupos marginalizados na arte.

A partir dessas novas configurações temáticas, novas interpretações poderão ser incentivadas, permitindo ao leitor a percepção sobre as formas pelas quais as mulheres são representadas, tornando-se críticos e atuantes da realidade social. A esse respeito Nelly Novaes Coelho (2000) considera que:

\footnotetext{
Quanto à moderna literatura destinada às crianças (ou à juventude), esta também apresenta um poder inerente a toda grande literatura e revela sua essencialidade quando é lida através dessa perspectiva: a do poder mágico do conhecimento, despertando a capacidade de inventar/construir como espaço de prazer, e, ao mesmo tempo, espaço de conhecimento subliminar. É essa fusão prazer/conhecer que encontramos nas raízes do chamado boom da literatura infantil em meados dos anos 70 - eclosão de uma nova qualidade literária e/ou estética que transformou o livro infantil em um objeto novo [...] possui matéria extremamente rica para formar ou transformar as mentes (COELHO, 2000, p. 127).
}

Segundo a autora, a linguagem estética procura representar a realidade em foco e dela ser testemunha, ao mesmo tempo em que se assume como invenção, passando a ser questionadora das realidades; e, ao mesmo tempo, descobre-se criadora ou instauradora de um novo real. Percebe-se também que nessas obras há as redefinições de identidades antes pré-estabelecidas uma vez que as obras de arte não mais apresentam o sujeito centrado e definido. O conceito de identidade vem sendo teorizado com mais ênfase a partir da intensificação e legitimação dos estudos culturais em meados do século XX. A obra A identidade cultural na pós-modernidade é um exemplo disso. Nela, o sociólogo Stuart Hall (2005) defende que não se pode falar da identidade como uma coisa acabada e estável e sim como um processo em andamento.

Essas transformações repercutiram e alicerçaram o desenvolvimento de teorias que procuraram explicar as novas configurações artísticas e ideológicas percebidas após o período 
entre guerras e a partir dos movimentos de resistência e contracultura. Uma delas foi desenvolvida por Linda Hutcheon (1991) que entende a pós-modernidade como um empreendimento contraditório, pois retoma o passado para em seguida desestabilizá-lo apontando para os próprios paradoxos, uma vez que incorpora e modifica a tradição, fazendo com que a memória funcione como um vínculo entre o ontem e o hoje, explicando uma mudança dentro da continuidade. Segundo a autora:

A maior contribuição da pós-modernidade tem sido um reconhecimento do fato de que qualquer sistema específico de significação da sociedade ocupa seu lugar em meio ao padrão total dos sistemas que estruturam a sociedade e que dele recebe sua confirmação (HUTCHEON, 1991, p. 58).

Assim, a literatura é uma forma de comunicação que permite entender não somente as formas de composição e interpretação do objeto artístico, mas também os efeitos das mudanças percebidas após grandes acontecimentos históricos registrados no século XX, o que fez com que novos contornos fossem estabelecidos. Percebe-se na arte temáticas eminentemente políticas e representativas de sujeitos que antes estavam à margem.

Nesse sentido, as novas formas de representações dos papéis de gênero têm começado a sugerir modos de desafiar e mudar as formas dominantes, nas várias dimensões da cultura, explorando novos tipos de simbologias na arte. Isso significa reavaliar sistemas sociais de poder, que validam e autorizam algumas imagens de grupos historicamente excluídos das produções artísticas.

Ressalte-se que a produção cultural é construída num contexto sociohistórico e numa ideologia e é nesse aspecto que as teorias feministas têm atuado. Os feminismos têm, nesse sentido, tido um efeito muito profundo no pós-modernismo. Não é por acaso que o pós-moderno coincide com a reavaliação feminista de formas não canônicas de discurso narrativo. Hutcheon (2002) reafirma essa premissa ao considerar a relação entre feminismo e pós-modernidade:

O pós-modernismo é certamente político, mas é politicamente ambivalente, duplamente envolvido com cumplicidade e crítica, subvertendo e mantendo ao mesmo tempo a posição metanarrativa. Devido à sua noção necessária de "verdade”, os 


\begin{abstract}
feminismos não são incrédulos em relação às suas próprias metanarrativas, mesmo se contestam a patriarcal. Eles certamente vão além de tornar a ideologia explícita e desconstruindo-a, argumentam sobre a necessidade de sua mudança para produzir uma transformação real da arte, que só pode vir com a transformação das práticas sociais patriarcais (HUTCHEON, 2002, p. 123).
\end{abstract}

Verifica-se que a narrativa contemporânea de Colasanti representa essas mudanças e faz uso da ironia como estratégia discursiva, porque ao mesmo tempo em que inscreve, subverte seu alvo, pois contesta os alvos culturais ao fazer uso de estratégias paródicas para questionar narrativas totalizadoras. Sobre essa questão, Giddens (2002) também cita a pós-modernidade, porém a denomina como Modernidade tardia, relacionando os sérios reflexos na estruturação e desenvolvimento da sociedade ao esvaziamento do tempo e do espaço:

[...] a condição de pós-modernidade se distingue por uma espécie de desvanecimento

da grande narrativa e a linha de relato englobadora mediante a qual nos coloca na história como seres que possuem um passado determinado e um futuro predizível (GIDDENS, 2002, p. 19).

Assim, é traço característico do pensamento pós-moderno a aceitação de uma totalidade fragmentada e heterogênea em contraposição à busca moderna pela homogeneização. Tal pensamento dá espaço à multiplicação das diferenças, permitindo que haja, no lugar da idealização de uma identidade estável e fixa, identificações sucessivas e provisórias.

Com base nessas considerações, discutiremos em que medida as personagens dos dois contos analisados nesse estudo representam essas transformações, especialmente pelas imagens poéticas presentes e atualizadas em narrativas destinadas para todos os públicos, não só para leitores em formação. 


\section{Num reino não muito distante...novas ideologias}

Construir e desconstruir, tecer e destecer: essas sejam algumas palavras que descrevem, de certa maneira, a obra literária de Marina Colasanti. Uma entre as mais significativas vozes femininas da literatura brasileira, principalmente pelo estilo peculiar de seus textos. Suas narrativas apresentam elementos insólitos e fantásticos incorporados ao enredo. Além disso, ao redesenhar a condição feminina, a autora retoma a trilha deixada por princesas e tecelãs em seus contos, que, apesar de esboçarem temáticas contemporâneas, apresentam estruturas e simbologias universalmente conhecidas.

O conto "Maria, Maria" foi publicado na coletânea Espinho de Marfim e outras histórias em 1999. Logo no início, já se percebe o conflito que motiva o desenrolar das demais ações: "Manhã de março. E a campainha toca. - Quem é? - pergunta Maria já ansiosa, na verdade inquirindo ao mundo por que me chamam em casa, o que querem de mim? - A senhora foi escolhida - responde o rapaz, tão louro atrás da corrente.” (COLASANTI, 1999, p. 35).

Maria, uma mulher moderna, tem nome homônimo ao personagem bíblico, recebe de uma pessoa que bate à sua porta uma notícia um tanto estranha. Logo pensa que é um vendedor ou oferece serviços que não queria pagar. "Fui escolhida para quê? pensa Maria, não ouço rádio, não entro em concurso, fui escolhida não, mentira." (COLASANTI, 1999, p. 35). Desconfiada da insistência do rapaz loiro de cabelos encaracolados, que se anuncia o "anjo do senhor", tal como a narrativa bíblica, Maria resolve ouvir o que o rapaz tinha a dizer.

O leitor aproxima essas ações à narrativa do nascimento de Jesus, pois há a semelhança com alguns elementos que aparecem atualizados. Mas a notícia do mensageiro não era nada agradável: ela está sendo despejada. Sozinha, grávida e agora despejada. Não resta outra opção senão começar a organizar a mudança antes da chegada do filho, porém vários obstáculos se apresentam:

Precisará ainda fazer a mudança, juntar suas coisas, depois acompanhar o caminhão com seu próprio carro, pequena procissão através do trânsito da cidade, durante a qual os cristais mais delicados, que levou consigo num balaio, tilintam como minúsculos sinos. Está justamente tentando definir lugares para os objetos na casa ainda caótica, quando o corpo moído exige que ela ponha as mãos nos rins e, projetando a barriga para a frente para aliviar o peso, Maria percebe que uma sombra se avoluma por 
dentro do ventre. Uma sombra que ainda não é dor, mas que cresce e, insistente, chama (COLASANTI, 1999, p. 36).

Há a (res)significação de mitos fundadores, porém adaptados ao cotidiano de uma "Maria" moderna. Para Costa (2008), "o mito foi a narrativa primeira através da qual o homem organizou seus símbolos, na necessidade de explicar o deslumbramento do mundo que acabara de nascer, e explicar-se nele (COSTA, 2008, p. 168)". Além disso, são frutos de impulsos humanos para apreender o indizível, o inexplicável, são resultados das crenças, do imaginado a partir de expressões coletivas, culturais, e, assim, projetam-se na história.

A narrativa descreve os dilemas de uma mulher moderna, com seus problemas, os estágios da gravidez até o momento do parto, e propõe um desenraizamento do patriarcado:

Frio, luz intensa, o corpo tão doído que quase o desconhece. Força, Maria, é preciso fazer força. Os músculos tensos, os dentes cerrados, o pescoço quase estourando. E de repente aquela sensação líquida, macia, de peixe esgueirando-se, saltando, como se a dor e o sangue e as vísceras de Maria se esvaíssem por entre suas pernas, deixando-a vazia e apaziguada (COLASANTI, 1999, p. 36).

A personagem começa a perceber aproximações de sua história com a narrativa bíblica, mas, após o parto, nasce uma menina. Maria então constata que o aviso do anjo era falso: - É uma menina - ouve o médico dizer do fundo da luz. Uma menina?! Então, pensa Maria quase com alívio antes de resvalar para o torpor, então não era verdade, nada do que o Anjo disse era verdade, eu não fui escolhida, sou apenas uma mãe qualquer, mãe da minha filha amada, que bem-vinda seja (COLASANTI, 1999, p. 40).

Ao sair da maternidade, Maria, com a filha no colo, entra no apartamento recém-alugado. Toda mudança por arrumar, o berço da criança ainda nem havia chegado, já era natal. Vê um caixote vazio, ainda com palha da mudança, arrasta-o para o meio da sala, afofa a palha, põe almofadas por cima e, com gestos de quem quara roupa ao sol, abre sobre as almofadas o lençolzinho branco, bordado, que estava guardado numa gaveta com sachê cheiroso, para o primeiro dia (COLASANTI 1999 p. 41). 
Em casa, um gato e um cachorro esperando seus cuidados, pois estavam sozinhos desde sua ida à maternidade. Enquanto arrumava comida para os dois, percebe que ambos contemplavam sua filha no caixote em devoção. Nesse instante, a personagem constata que o milagre que o anjo anunciara estava se repetindo, não da mesma forma da narrativa bíblica, mas condizente com o modo de vida de uma mãe que, como muitas da vida real, enfrentam seus problemas sem a intervenção da figura masculina. A personagem tem a certeza de que a menina é sagrada:

[...] faz barulho com o prato. Nada. Que será que há com esse bichos, se pergunta Maria. Intrigada, vai até a sala. Não chega a entrar, porém, retida por um instante na porta, em devoção. Lá está o caixote, onde ela o deixou. Mas o gato de um lado e o cachorro do outro bafejam delicadamente sobre a menina. E acima dela, pairando ofuscante na tarde que se vai, esparge sua fúlgida luz uma estrela. - Então era verdade! O Anjo não mentiu! Ajoelha-se Maria perto da filha. Sim, o Anjo disse a verdade. Sagrada é a menina que esperneia entre linhos. Como estava prometido, Ela chegou. Louvor aos céus, pois a Messias está entre nós (COLASANTI, 1999, p. 40).

No desfecho do conto, há novamente a retomada da história bíblica do nascimento de Jesus, mas dessa vez com uma menina sendo "a Messias". Os animais ao redor, a luz da estrela, a menina sagrada nasceu! Percebe-se no enredo do conto que a história de nascimento de Jesus é recontada, mas com algumas mudanças: o bebê nascido na noite de natal era uma mulher, Maria estava sozinha no momento do nascimento. A mulher assume a responsabilidade sozinha de cuidar da filha, dos animais de estimação e da casa, o que atualiza a narrativa tradicional mais conhecida entre os cristãos. Essas imagens configuradas em arquétipos acabam se transfigurando e permanecendo nas narrativas tradicionais e modernas, permitindo análises sobre seus constituintes. O conceito de arquétipo foi introduzido na ciência contemporânea pelo psicanalista Carl Gustav Jung (2000), que desenvolveu uma teoria baseada no imaginário, mostrando que valores e costumes repousam em imagens gerais e primordiais que determinam inconscientemente o pensamento, o que ele denomina de arquétipos coletivos. Isto é, o arquétipo em si é imperceptível, um princípio ordenador cujos elementos provenientes do inconsciente coletivo (compostos de conteúdos universais 
e transpessoais) estruturam e coordenam o funcionamento da psique. Para Gilbert Durand (1989), um estudioso da teoria junguiana,

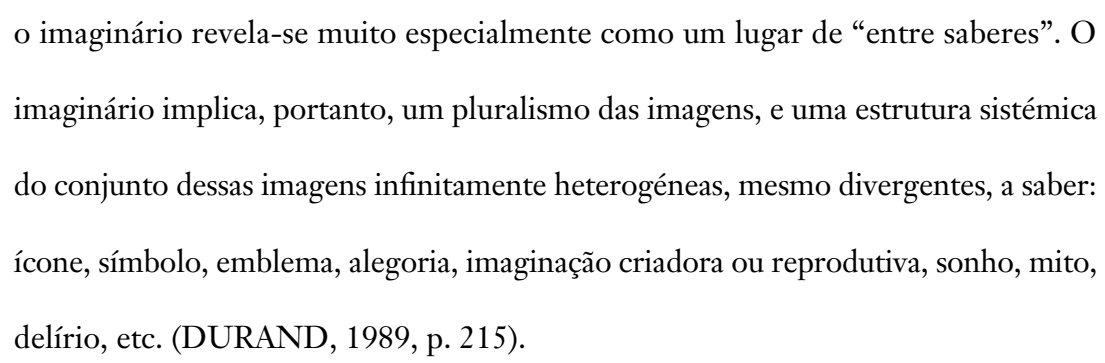

É importante ressaltar que esta capacidade de organização é herdada, enquanto o conteúdo ou as imagens arquetípicas sofreram as influências do meio. Isto é, os modelos arquetípicos básicos ou núcleos estruturantes são universais, são comuns a todos os povos, a todos os indivíduos e persistem com o passar do tempo.

Sobre essas novas imagens poéticas, Marisa Lajolo e Regina Zilberman (2005), ao fazerem referência à produção literária de Colasanti, enquadram-na entre aqueles que "apontam para outros caminhos que sugerem o esgotamento da representação realista", e afirmam que "a escrita colasantiana revigora o fantástico com requintes de surrealismo e magia." (LAJOLO; ZILBERMAN, 2005, p. 175). A autora recupera imagens e símbolos universais e reinterpreta imagens e papeis de gênero, colocando a mulher como protagonista e detentora dos espaços de poder.

É importante considerar que mesmo influenciado diretamente pela herança dos contos de fadas da tradição, esse e outros textos de Marina Colasanti trazem as marcas de alguns paradigmas que estruturam a sociedade moderna, sobretudo, sob a perspectiva feminina. Sobre essas abordagens, Zolin (2009) afirma que:

\footnotetext{
é nesse contexto, então, que a mulher, tomada como o “outro", em relação ao homem - sua cultura, seus pressupostos estéticos e ideológicos - que é considerado “o mesmo", ou o "centro", passa a atrair para si olhares interessados em desnudar os mecanismos que lhe constituem o modo de ser, de estar na sociedade e de se fazer representar, seja na esfera social, com o movimento feminista, seja na literária, um pouco mais tarde, com a crítica feminista (ZOLIN, 2009, p. 239).
} 
A autora corrobora com as novas tendências percebidas na arte nos últimos tempos. Entende-se que a reconstrução dessas temáticas, a partir do discurso artístico, permite uma pluralidade de enfoques através de narrativas que buscam na tradição coletiva uma relativa estabilidade, configuradas por meio do inconsciente humano e, na modernidade, atualizadas com questionamentos relacionados à misoginia condizem com paradigmas pós-modernos.

A esse respeito, Foucault (1993) defende que a construção ideológica é sintetizada enquanto uma relação entre verdade e poder e, assim, todos os discursos podem ser vistos funcionando como regimes de verdade. Segundo o autor:

\footnotetext{
Cada Sociedade tem seu regime de verdade, sua 'política geral' de verdade: isto é, os tipos de discurso que aceita e faz funcionar como verdadeiros; os mecanismos e instâncias que permitem distinguir entre sentenças verdadeiras e falsas, os meios pelos quais cada um deles é sancionado; as técnicas e procedimentos valorizados na aquisição da verdade; o status daqueles que estão encarregados de dizer o que conta como verdadeiro (FOUCAULT, 1993, p. 131).
}

Por isso, se no passado era comum ver mulheres subjugadas e inertes frente a uma sociedade patriarcal e misógina, atualmente as personagens, em sua maioria, reescrevem novas histórias e mudam seus destinos mesmo diante de interdições impostas ainda que silenciosamente. $\mathrm{Na}$ Literatura, é comum a reinterpretação de estilos tradicionais, como o conto de fadas clássico, buscando em seguida desestabilizar suas verdades.

Assim, a pós-modernidade também é marcada pela contradição mesmo retomando estruturas antigas, pois ao mesmo tempo em que estabelece laços com o passado, também desestabiliza a partir de dentro. Ademais, essas tendências permitem investigar a relação da ideologia e do poder com todas as nossas atuais estruturas discursivas. Seja a paródia ou o pastiche, ambos compartilham da mesma característica de resgatar o passado reavaliando as estruturas e ideologias legitimadas ao longo dos anos.

Contudo, é importante considerar que este caráter subversivo e desafiador tende a ser uma estratégia dos artistas fora do centro (negros, gays, feministas e demais minorias étnicas). "Que tenham um acerto de contas e uma relação à cultura ainda predominantemente branca, heterossexual e masculina na qual se encontram" (HUTCHEON, 1991, p. 58), o que se 
enquadra na arte como forma de protesto produzida por Marina Colasanti ao retomar uma história bíblica, porém com uma nova roupagem.

Com uma temática semelhante, o conto "Com sua voz de mulher", publicado no livro Longe como meu querer (2006), é ambientado numa pequena cidade com costumes arcaicos. O modo de vida é simples, voltado para o cultivo da terra. Inicialmente, a autora apresenta a figura de um deus que controlava tudo o que se passava naquele lugar. Entretanto, uma situação o (a) intrigava: os habitantes desta cidade estavam sempre insatisfeitos, mesmo com campos férteis e rebanhos com inúmeros animais; não sorriam, estavam sempre tristes.

Percebe-se no início da história o conflito central que desencadeará as ações até sua solução. Primeiramente, o deus resolve ir até a aldeia para saber o motivo de tantas tristezas, conforme a seguir:

\footnotetext{
- ,Nada lhes falta, disse o deus, em voz alta. Cuido para que as estações se sigam em boa ordem. Garanto-lhes colheita no campo e comida na mesa. Nenhum grão apodrece nas espigas. Nenhum ovo gora nos ninhos. E seus filhos crescem. Por que então não são felizes? Um dia, pelas preces, percebeu que os habitantes não eram felizes (COLASANTI, 2006, p. 280).
}

Como não obteve uma resposta clara para tal pergunta, resolveu apresentar-se no mundo dos mortais e procurou uma aparência para descer à Terra. Ao observar seu imenso guarda-roupa, escolheu, entre todas as criaturas, uma figura humana, e entre todas optou pela pele mais lisa e macia que encontrara. Ele viria à terra no corpo de uma mulher.

Diante de um deus em corpo de mulher, grande foi o espanto das pessoas. Afinal, para elas, uma mulher nunca poderia exercer essa função. Então, logo que se apresentou, a personagem foi alvo de desconfianças, conforme descrito a seguir:

E eis que aquela mulher de longos cabelos apareceu na cidade dizendo que era deus, e ninguém acreditou. Fosse deus, teria vindo como guerreiro, herói, ou homem poderoso. Fosse deus, apareceria como leão, touro bravio ou águia lançando-se das nuvens. Até o crocodilo e a serpente poderiam abrigar deus em seu corpo (COLASANTI, 2006, p. 47). 
A desconfiança foi comum a todos, "mas uma mulher vinda das ruas estreitas nada mais podia ser que uma mulher" (COLASANTI, 2006, p. 48). A autora deixa entrever de uma forma simbólica que o discurso ficcional faz lembrar a maneira como a mulher foi retratada no passado permitindo outros olhares. Discurso por muito tempo legitimado nas escrituras sagradas, que assegurava ao gênero masculino a função de patriarca, chefe religioso, líder da tribo, ou seja, à mulher sempre restava uma posição secundária. Então, diante do aparecimento do deus-mulher, a desconfiança da população foi geral, conforme descrito a seguir:

E assim o deus prendeu seus longos cabelos sobre a nuca e foi procurar um trabalho. Mas a uma mulher não se dá trabalho de ferreiro, nem se põe na carroça a conduzir cavalos. Uma mulher não é aquela que comanda soldados. Uma mulher não é sequer aquela que conduz o arado. E depois de muita procura, o deus-mulher só conseguiu empregar-se em uma casa para ajudar nas tarefas domésticas (COLASANTI, 2006, p. 48).

Essa representação comprometida é observada neste conto, pois sugere interpretações sobre a quebra de estereótipos por muito tempo conferidos a homens e mulheres. E, em se tratando de obras voltadas para crianças e jovens, essas imagens vêm carregadas de simbologias. Pois, ao descrever a reação adversa daqueles habitantes após a constatação que o deus tinha corpo de mulher, na verdade a autora concretiza imagens simbólicas presentes no imaginário coletivo de várias épocas e culturas.

Depois de perceber a desconfiança do povo sobre sua aparência, o deus-mulher tentou encontrar trabalho em várias funções que eram essencialmente masculinas; porém, a única ocupação que conseguiu foi de doméstica, em uma casa simples. E na casa em que escolheu morar, a família, apesar de tudo parecer favorável, não sorria. Os habitantes repetiam diariamente seus afazeres com a mesma tristeza que se via em todas as moradias daquele lugar:

E os filhos cresciam como crescem filhos que não têm doenças. Porém, pouco sorriam. Cumpriam suas tarefas de dia. À noite juntavam-se no estábulo para aproveitar o calor dos animais. As mulheres fiavam. Os homens consertavam ferramentas ou faziam cestos. Ninguém falava. As noites eram longas depois de longos dias. Os humanos se entediavam (COLASANTI, 2006, p. 49). 
Essa situação começou a mudar quando o deus resolveu contar histórias aos moradores daquela casa. Logo, todos ficaram atentos e sentiram-se atraídos pelas narrativas contadas. Posteriormente, a conduta dos membros daquela família foi se alterando:

\footnotetext{
Contou uma história que se havia passado no seu mundo, aquele mundo onde tudo era possível e onde viver não obedecia a regras pequenas como as dos homens. Era uma longa história, uma história como ninguém nunca havia contado naquela cidade onde não se contavam histórias. $\mathrm{E}$ as mulheres ouviram de olhos bem abertos, enquanto o fio saía fino e delicado entre seus dedos. E os homens ouviram esquecidos de suas ferramentas. E o menino que chorava adormeceu no colo da mãe. E as outras crianças vieram sentar-se aos pés do deus. E ninguém falou nada enquanto ele contava, embora em seus corações todos estivessem contando com ele (COLASANTI, 2006, p. 47).
}

A transformação começou a partir dessa ação. As estórias contadas despertaram naqueles habitantes sentimentos nunca vividos, motivaram reações novas. Nesse sentido, as configurações simbólicas que a autora resgata e retoma relembram temas presentes nas narrativas primordiais, e se apropria da forma e da estrutura das histórias clássicas que começaram a ser registradas no século XVII, uma vez que a tarefa de contar histórias era essencialmente feminina.

A autora também afirma que, tão remoto quanto a origem da humanidade, o ato de ouvir e contar histórias não é apenas um dos muitos hábitos que os homens foram desenvolvendo ao longo de sua existência. Na verdade, trata-se de um ato de prazer, cuja finalidade é exatamente fugir aos hábitos rotineiros que marcam a monotonia da vida cotidiana. $\mathrm{E}$ a mulher sempre teve um papel de destaque no mundo das histórias, seja como personagem, seja como deusa sacerdotisa, num ritual sagrado, ou como simples ama, tia, mãe, avó que, enquanto fiava, ia traçando com palavras os fios das narrativas populares, transmitidas de geração a geração.

Entende-se que todos esses constituintes que perpassam as narrativas maravilhosas contemporâneas representam caminhos para o entendimento de suas configurações literárias e se desvencilharam da reprodução de valores patriarcais, se atualizando com os novos tempos e os novos discursos. Porém, mantiveram-se a estrutura, o desenvolvimento e construção das personagens. O que hoje, permite novas configurações na recepção dessas obras ao despertar novas consciências. 
O conto mostra a mudança que as histórias contadas pelo deus representou para aquelas pessoas. Inicialmente, apenas a família a hospedara, depois um vizinho foi chamando o outro e mais outro. Em pouco tempo, boa parte dos habitantes daquela cidade se interessou e passou a integrar o grupo de ouvintes. A partir de então, operava-se uma transformação significativa em todos, conforme trecho descrito a seguir:

\footnotetext{
Agora, durante o dia, enquanto aravam, martelavam, enquanto erguiam o machado, os homens lembravam-se das histórias que tinham ouvido à noite, e tinham a impressão de também navegar, voar, cavalgando trovões e nuvens como aquelas personagens. E as mulheres estendiam lençóis como se armassem tendas, repreendiam o cão como se domassem leões, e atiçando o figo chuçavam dragões. Até o pastor com suas ovelhas não estava mais só, e as ovelhas eram sua legião (COLASANTI, 2006, p. 50).
}

A fantasia passou a ter espaço na vida daqueles moradores, de modo que a ficção presente naquelas histórias possibilitou a eles um novo olhar frente às suas realidades. Antes não sorriam; depois de conhecer todas aquelas aventuras, passaram a ver o mundo de outra forma, os afazeres diários passaram a ser menos cansativos, a vida passou a ter outro significado. As narrativas permitiam que elas lembrassem constantemente dos fatos e personagens que viviam em universos maravilhosos e perfeitos. "Os homens sorriam debruçados sobre suas tarefas, as mulheres cantavam e tinham gestos amplos nos braços" (COLASANTI, 2006, p. 50).

No desfecho do conto, a autora permite entrever que aquela transformação havia apenas começado. Outra mulher passou a repetir as histórias, depois mais pessoas repetiram o mesmo gesto, a ponto de ninguém saber mais quem havia começado a contá-las.

Assim, após a análise dos dois contos colasantianos, percebeu-se o resgate de narrativas milenares e do imaginário antigo. Nesse aspecto, existem símbolos nas suas formas arquetípicas fundamentais que, quanto mais profundos ou arcaicos, mais coletivos e universais serão, ao passo que, estando eles mais próximos da camada consciente, mais específicos e singulares serão. Deste modo, perdem seu caráter universal. Ao se tentar explicitar mais claramente a noção de arquétipo e sua diferenciação da ideia de imagem arquetípica, buscam-se argumentos para demonstrar a identidade que há entre mito e contos de fadas cujos motivos básicos têm origem nas camadas profundas do inconsciente, comuns à psique de todos os humanos. 
Seguidora da teoria junguiana, a pesquisadora Marie-Louise Von Franz (2010) concentrou parte de suas pesquisas na análise dos papéis femininos nos contos de fadas tradicionais. Segundo seus estudos, "os contos de fadas são a expressão mais pura e simples dos processos psíquicos do inconsciente coletivo" (FRANZ, 2010, p. 19), destarte, eles têm grande valor para a investigação coletiva do inconsciente. A autora assinala que atualmente há um crescente interesse do público por essa forma de literatura popular, o que contribuiu para o aprofundamento de estudos científicos e literários relacionadas a essas manifestações de arte. Von Franz (2010) considerou os contos de fadas como fonte de compreensão da psique e do comportamento humano, e engendrou questões complexas sobre as projeções que as imagens arquetípicas estabelecem nessas narrativas ficcionais.

Sonia Salomão Khéde (1986) defende a importância das origens históricas dessas narrativas, sendo necessário considerar os fatores que codificam os elementos próprios de cada época, um padrão institucionalizado tanto para escritores como para leitores. Nesse aspecto, a autora afirma que:

\footnotetext{
A literatura infantil e juvenil é um gênero marcado historicamente. Desse modo, os gêneros infantis sempre evidenciarão traços constitutivos da sociedade atual da qual fazem parte e apontarão para as ideologias provenientes dos conflitos históricos. A singularidade do gênero literário infantojuvenil estaria justamente na sua indiscutível complexidade histórica, responsável, também, pelas inúmeras nuances ideológicas que entrecortam seus textos (KHÉDE, 1986, p. 9).
}

Dessa forma, os contos de fadas, as lendas, e os mitos também deixaram de ser vistos apenas como "entretenimento infantil" e vêm sendo redescobertos como autênticas fontes de conhecimento do homem e de seu lugar no mundo. Desde suas origens, essas histórias, bem como as narrativas religiosas a elas relacionadas, ofereciam um material a partir do qual as crianças formavam seus conceitos da origem e do propósito do mundo, e os ideais sociais que lhes poderiam servir de modelo. Neste sentido, apoiamo-nos em Barthes (1985) que afirma que:

O mito não nega as coisas; a sua função é, pelo contrário, falar delas; simplesmente, purificá-las, inocentá-las, fundamentá-las em natureza e em eternidade, dá-lhes clareza não de explicação, mas de constatação, abole a complexidade dos atos hu- 
manos, confere-lhes a simplicidade das essências, suprime toda e qualquer dialética (BARTHES, 1985, p. 163).

Entende-se que todos esses constituintes que perpassam as narrativas maravilhosas contemporâneas representam caminhos para o entendimento de suas configurações literárias e se desvencilharam da reprodução de valores patriarcais, se atualizando com os novos tempos e os novos discursos. Porém, mantiveram-se a estrutura, o desenvolvimento e construção das personagens. O que, hoje, permite novas configurações na recepção dessas obras ao despertar novas consciências.

Assim, os contos analisados possibilitam a (re)construção da imagem feminina em contornos contemporâneos, comprovando a condição literária pós-moderna ao admitir discursos plurais que entrelaçam estilos e vozes. O que permite retomar o conceito de metaficção, conceituada por Hutcheon (1991), pois são obras que refletem sobre sua própria condição de ficção, explorando temáticas que expõem a ficcionalidade da própria história ao apresentar personagens conhecidas, mas submetidas a distorções, falsificações e ficcionalizações.

Desse modo, assim como defende Teresa Lauretis (1994), gênero é uma representação em permanente construção por diversas "tecnologias", como a família, as escolas, os meios de comunicação, os movimentos sociais e as práticas artísticas como a literatura. Por isso, a construção do gênero também se faz por meio de sua desconstrução, uma vez que as representações de gênero devem tocar o que também está fora do discurso para assim desestabilizar qualquer representação tradicional.

\section{Considerações finais}

Com base nas análises dos contos "Maria, Maria" e "Com sua voz de mulher", percebeu-se traços comuns: as protagonistas agem de forma desafiadora em relação a ordem constituída, protagonizam histórias que reescrevem mitos religiosos, uma vez que reinterpretam verdades absolutas que colocavam a figura masculina em destaque. A “messias" e o “deus-mulher” propõem novas visões em relação aos papéis de gênero. 
Ademais, a tessitura narrativa presente nesses contos coloca a figura feminina duplamente em evidência: primeiramente, por uma mulher representar um deus e depois por reescrever seus próprios destinos.

Assim, mesmo apresentando uma temática atualizada ao nosso tempo, nas narrativas colasantianas podem-se verificar influências remanescentes da tradição e a constatação que, na pós-modernidade, a escrita feminina aparece também na posição de porta-voz de vivências comuns a todas as mulheres. Retomando o passado sem desacreditá-lo.

Entende-se que as obras de Marina Colasanti e de outras importantes autoras da contemporaneidade agem na contramão da ordem vigente, representando em seus textos personagens questionadoras, que procuram respostas para suas angústias, e que também buscam a liberdade para assumirem sua própria identidade, mesmo inseridas em um meio social em que prevalecem os valores do senso comum, ditados pela ideologia patriarcal.

Além da quebra de paradigmas estabelecidos, outro ponto em comum entre os dois contos apresentados neste estudo são as imagens, as metáforas e o trabalho artístico com a linguagem. As narrativas apresentam várias indicações que permitem ao leitor atualizar os sentidos e suas visões de mundo, uma vez que mobilizam um universo carregado de significações que permitem perceber, através do fantástico, do onírico e do maravilhoso, autênticas formas de autoconhecimento e de seu lugar no mundo, a partir da repetição ou reiteração de esquemas básicos acessíveis à mente desses leitores. Assim, Colasanti propõe uma realidade “outra”, aponta as representações de gênero com uma roupagem nova e criativa, deixando espaço para o leitor interagir e descobrir o que está na tessitura do texto.

Ademais, a produção literária contemporânea voltada para crianças e jovens representa uma linha da literatura atual "que se volta para o passado inaugural (mítico ou histórico), como uma busca ou resgate das raízes do início, do húmus vital necessário à semeadura do Presente que se está engendrando como Recomeço" (COELHO, 2000, p. 131). Isso pode despertar questionamentos e põe às claras desequilíbrios que precisam ser conscientizados e discutidos por toda a sociedade, até que possam ser resolvidos. A literatura, além de fonte de prazer emocional, está desempenhando essa tarefa de conscientização.

A partir das análises realizadas neste estudo, pode-se observar que as narrativas juvenis atuais apresentam uma autonomia temática e consolida seu compromisso com o padrão estético 
da linguagem, sem a finalidade de apresentar comportamentos a serem imitados, retomando estruturas tradicionais, mas com um discurso ideológico questionador. Colasanti, ao compor seus textos, reconhece a função emancipadora e libertadora da literatura e resgata sua conotação crítica, já que a mulher aparece como porta-voz de suas experiências. 


\section{Referências}

BARTHES, Roland. O mito, hoje. In: Mitologias. Ed. Difel, São Paulo, 1985.

BETTELHEIM, Bruno. A psicanálise dos contos de fadas. Trad. Arlene Caetano. Rio de Janeiro: Paz e Terra, 2006.

BONNICI, Thomas. Teorias Estruturalistas. In: BONNICI, Thomas; ZOLIN, Lúcia Osana (Org.). Teoria Literária: abordagens históricas e tendências contemporâneas. 3. ed. Maringá: EDUEM, 2009. p. 117-142.

COELHO, Nelly Novaes. Literatura: arte, conhecimento e vida. São Paulo: Petrópolis, 2000.

COLASANTI, Marina. Um espinho de marfim e outras histórias. Porto Alegre: L\&PM, 1999.

COLASANTI, Marina. Longe como o meu querer. 2.ed. São Paulo: Ática, 2006.

COSTA, Maria Edileuza da. Lindoia, moema ... carolina, iracema: mitos românticos da literatura brasileira. Interdisciplinar: Revista de estudos em Língua e Literatura . $\mathrm{n}^{\circ} 7$. Aracaju/SE. UFS 2008. Disponível em https://seer.ufs.br/index.php/interdisciplinar/issue/view/132/showToc. Acesso em 23 de abr. 2019.

DUARTE, Constância Lima. Literatura feminina e crítica literária. Travessia Revista de Literatura Brasileira da UFSC, Florianopolis, v. 21, n. 2, 1990, p. 48-64.

DURAND, Gilbert. As estruturas antropológicas do imaginário. Lisboa: Presença, 1989.

FOUCAULT, M. Microfísica do poder. Rio de Janeiro: Graal, 1993.

FRANZ, Marie-Louise Von. O feminino nos contos de fadas. São Paulo: Edições Paulinas, 2010. 
GIDDENS, A. Modernidade e Identidade. Tradução P. Dentzien. Rio de Janeiro: Jorge Kahar, 2002 .

HALL, Stuart. A identidade cultural na pós-modernidade. Trad. Thomas Tadeu da Silva e Guacira Lopes Louro. 11. Ed. Rio de Janeiro: DP\&A, 2005.

HUTCHEON, Linda. A incredulidade a respeito das metanarrativas: articulando pós-modernismo e feminismos. Trad. Margareth Rago. Labris - Estudos Feministas, n. 1-2, julho/dezembro de 2002.

. Uma teoria da paródia. Trad. Teresa Louro Peres. Lisboa: Edições 70, 1991.

JAMERSON, F. Pós-modernismo: a lógica cultural do capitalismo tardio. $2^{\text {a }}$ Ed. São Paulo: Ática, 2006

JUNG, Carl Gustav. Arquétipos e inconsciente coletivo. Tradução Maria Luíza Appy, Dora Mariana R. Ferreira da Silva. Petrópolis, RJ : Vozes, 2000.

LAJOLO, Marisa. No reino do livro infantil. In: ZILBERMAN, Regina (Org.) Os preferidos do público: os gêneros da literatura de massa. Petrópolis: Vozes, 2005.

LAURETIS, Tereza de. A tecnologia do gênero. In: HOLLANDA, H. B. (Org.). In: HOLLANDA, H. B. (Org.). Tendências e impasses: o feminismo como crítica da cultura. Rio de Janeiro: Rocco, 1994, p. 206-242.

MENDES, Mariza. Em busca dos contos perdidos: o significado das funções femininas nos contos de Perrault. São Paulo: Editora da UNESP / Imprensa Oficial do Estado de São Paulo, 2000. 
SOARES, Lívia Maria Rosa. Representações Femininas nos contos de fadas de Marina Colasanti. Dissertação (Mestrado em Letras) Universidade Estadual do Piaui, Teresina, 2014.

PERRAULT, Charles. Contos de Perrault. (Tradução de Regina Regis Junqueira). Belo Horizonte: Vila Rica, 1994.

TURCHI, Maria Zaíra, SILVA, Vera Maria Tietzmann (Orgs.). Leitor formado, leitor em formação: leitura literária em questão. São Paulo: Cultura Acadêmica, 2006.

YUNES, Eliana; PONDÉ, Glória. Leitura e leituras da literatura infantil. São Paulo: FTD, 1998. ZOLIN, Lúcia Osana. Crítica feminista. In: BONNICI, Thomas; ZOLIN, Lúcia Osana (Org.). Teoria Literária: abordagens históricas e tendências contemporâneas. 3. ed. Maringá: EDUEM, 2009. p. 217-242.

ZOLIN, Lucia Osana. Desconstruindo a opressão: a imagem feminina em "A República dos sonhos” de Nèlida Pinõn. Maringá: EDUEM, 2003. 